\title{
INVESTIGATION OF THE MINERALOGICAL PETROGRAPHIC, GEOCHEMICAL AND PHYSICAL PROPERTIES OF CARBONATE ROCKS FROM ILEIA PREFECTURE AND ASSESMENT FOR INDUSTRIAL APPLICATIONS
}

\author{
Tseni X. ${ }^{1}$, Koutsopoulou, E. ${ }^{1}$, Tsikouras B. ${ }^{1}$, Hatzipanagiotou K. ${ }^{1}$ \\ ${ }^{1}$ University of Patras, Department of Geology, Section of Earth Materials, 26500 Patras, Greece \\ tseni@upatras.gr, ekoutsop@upatras.gr,v.tsikouras@upatras.gr,k.hatzipanagiotou@upatras.gr
}

\begin{abstract}
Research on carbonate rocks has been increasingly important during the last few decades, due to their numerous applications. In this paper, we examined the properties of Cretaceous carbonate rocks from the Olonos-Pindos Zone from Ileia Prefecture. The relationships between various physical properties and between petrographic features and physical properties were defined. This may lead to preliminary evaluation of carbonate rocks using microscopic investigation, which unlike the elaboration of a series of physical and mechanical properties, is a fast and inexpensive method. In addition, these properties, along with their geochemical characteristics, were used to assess the suitability of these carbonate rocks as fillers in various applications. Detailed petrographic study of the collected samples revealed the occurrence of biomicrite, intramicrite (mudstone kal wackestone), biosparite (packstones and grainstones), intrasparite and rudstone. From the lower to the upper members, a decrease of the grain size of calcite is observed. X-ray diffraction study of the insoluble residue revealed the presence of quartz, chlorite, illite, smectite, and mixed layer illite-chlorite. The colour index of the investigated powdered samples is negatively influenced by the increase of organic and insoluble residue contents. The water absorption is inversely correlated with $\mathrm{CaO}$ content while moisture is positively correlated with insoluble residue. The grainstone and rudstone are characterized as ultra-high pure calcium limestones, except for Mg-rich crystalline dolomitic limestones. The packstones are calcium limestones of high to medium purity. Mudstones and wackestones are characterized as low calcium limestones. The results suggest that all the examined lithotypes can be used as soil conditioners and animal feed supplements; however only grainstones and rudstones are suitable for desulphurization of exhaust gasses and cement production.
\end{abstract}

Key Words: limestone, physical properties, Pindos Zone, Peloponnesus

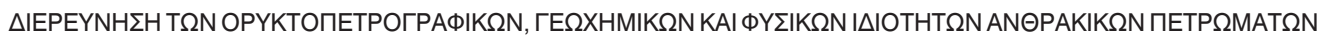
TOY NOMOY HAEIA $\Sigma$ KAI EKTIMH $\Sigma H$ TH $\Sigma$ KATAMHНOTHTA $\Sigma$ TOY $\Sigma$ $\Sigma$ E BIOMHXANIKE $\Sigma$ EФAPMOГE $\Sigma$

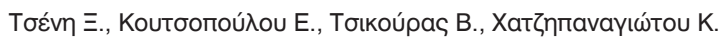




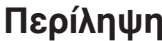

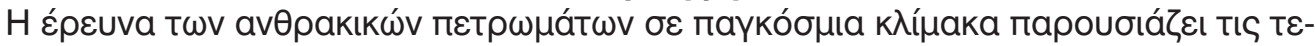

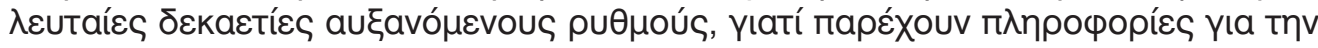

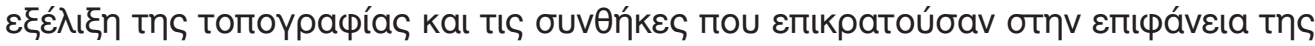

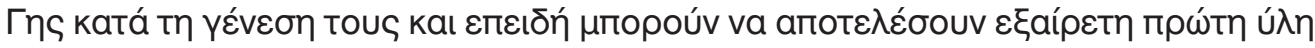

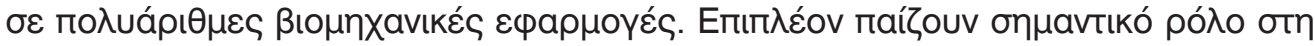

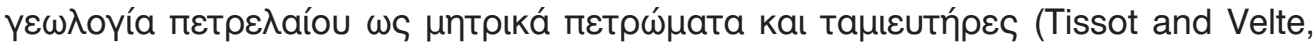

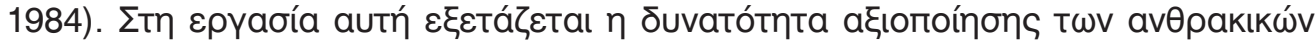

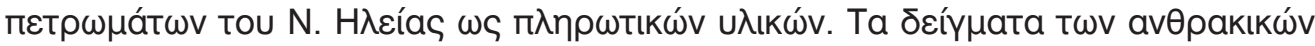

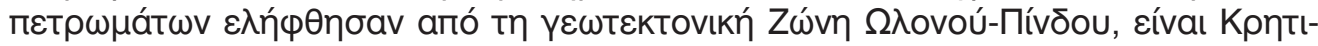

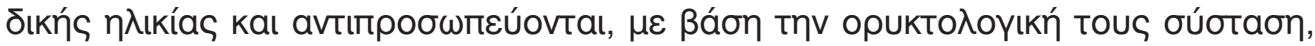

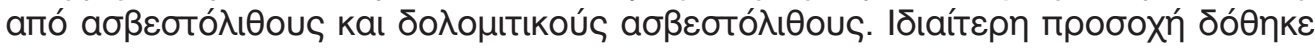

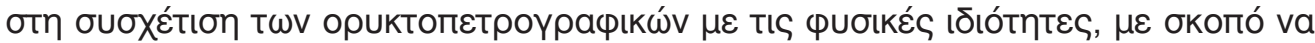

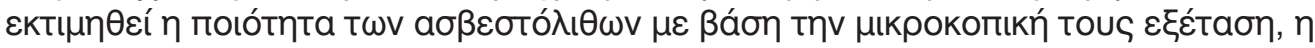

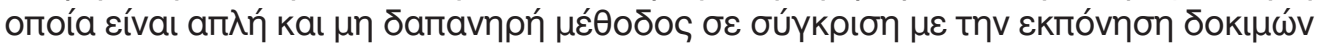

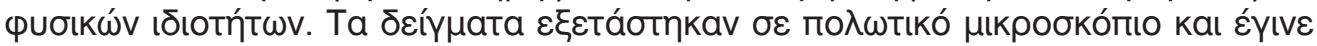

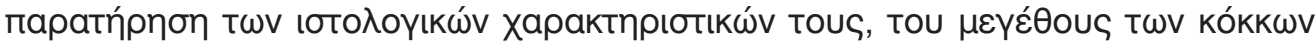

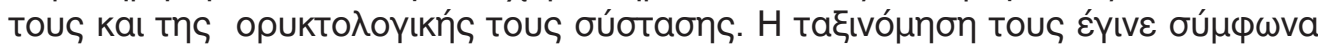

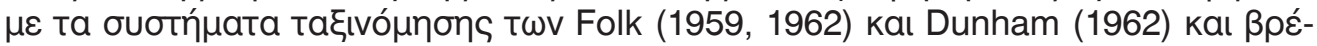

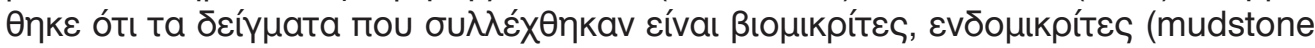

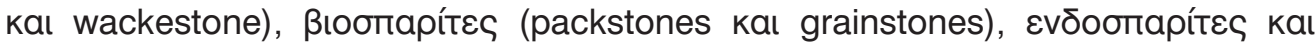

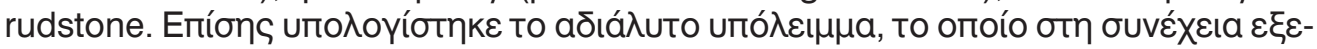

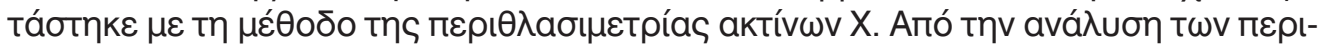

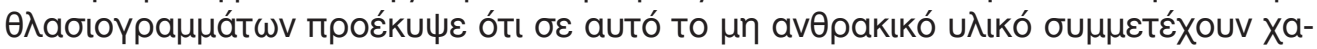

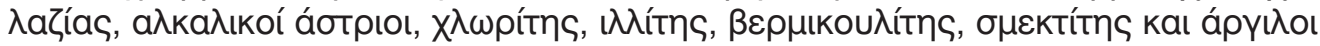

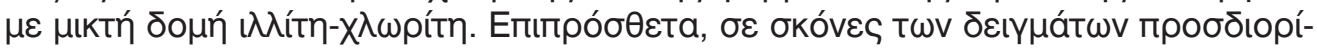

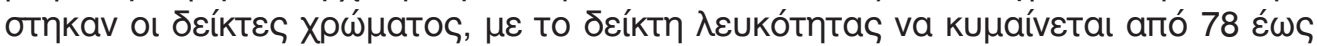

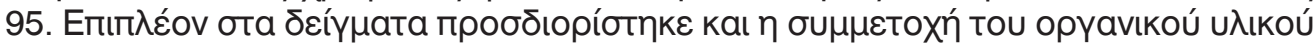

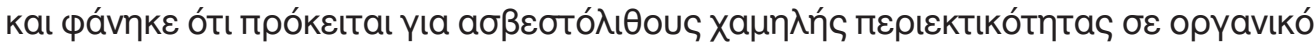

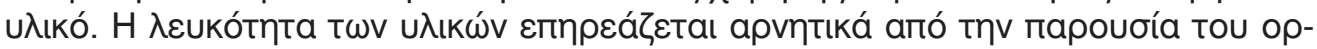

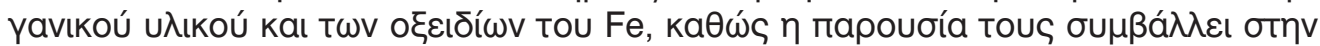

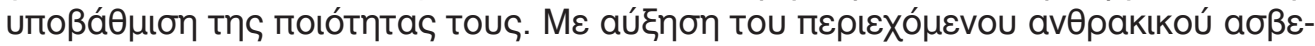

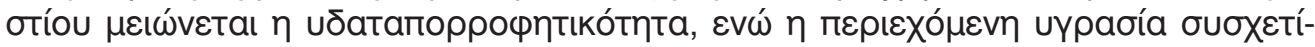

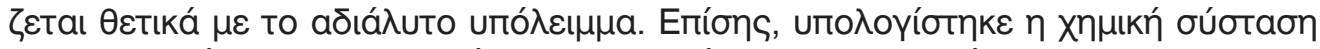

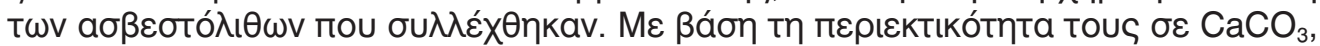

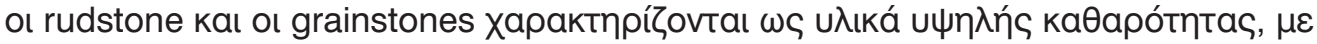

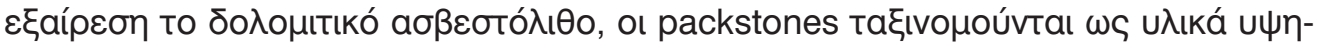

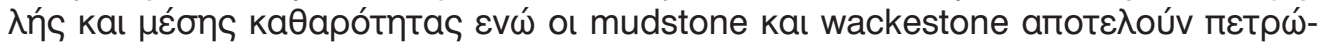

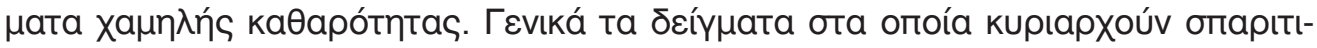

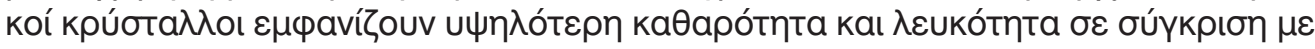

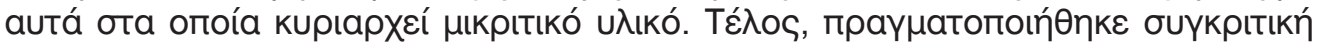

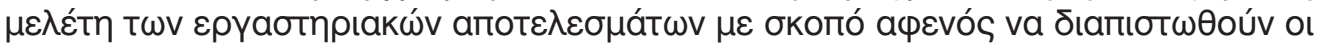

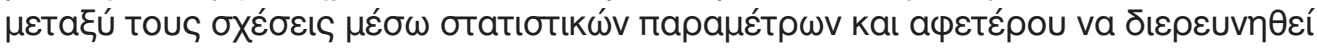

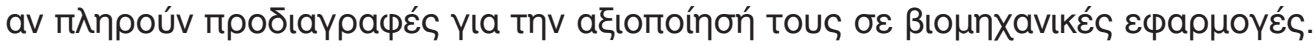

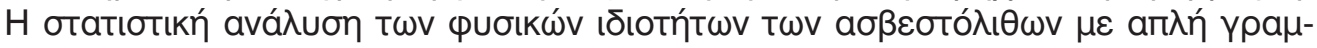

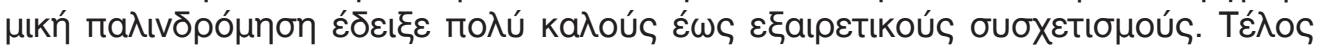




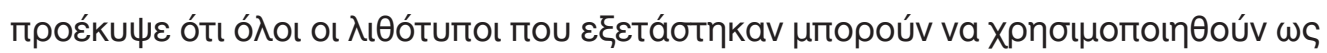

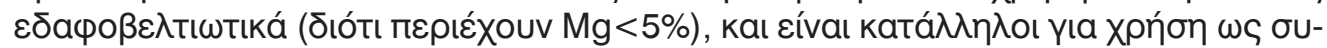

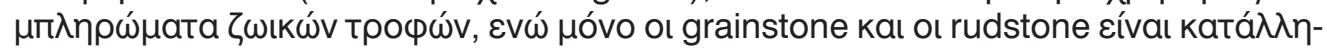

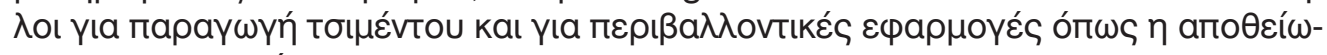

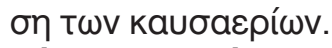

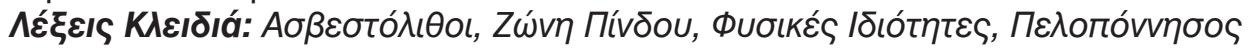

\section{Introduction}

Limestones are industrial rocks which are mainly used as crushed rocks for construction purposes, as dimension stones and fillers in concrete, and as road aggregates. Generally, limestone can be used in cement when the $\mathrm{Mg}$ content is below $5 \%$, because high $\mathrm{Mg}$ contents causes expansion after setting, hence reducing its strength. Ground limestone is widely used to raise the $\mathrm{pH}$ of acid soils, as well as an additive in fertilizers and animal foodstuffs. Large amounts of limestone are used in blast furnaces as slag conditioners and in the steel production to form slag; however the large amounts of energy that required to decompose limestone to lime generally limits its use. Limestone is widely used as a fluxing agent in smelting of metals, as well as in bauxite processing and production of alumina. The most widespread use of limestone is the production of quicklime.

Petrophysical properties of sedimentary rocks are influenced by size, shape, and packing of grains, porosity, cement and matrix content, all controlled strongly by depositional fabric and postdepositional processes. This paper aims at investigating the physical properties of Cretaceous limestones from the Pindos Zone of lleia Prefecture, in order to establish their inter-relationships, to study the relationships of physical properties with their petrographic characteristics and to evaluate their suitability as indus- trial rocks in various applications. These limestones are the most abundant in the investigated area occupying approximately $72 \mathrm{~km}^{2}$, including a large variety of different lithotypes. They are also of potential industrial interest; hence study of their physical properties is important.

\section{Geological setting}

The geological setting of the lleia Prefecture, west Peloponnesus, is characterized by the presence of the lonian, the Gavrovo-Tripolitza and the Olonos-Pindos geotectonic Zones. During the Mesozoic, the lonian zone corresponded to a vast, intra-platform rift basin bounded on both sides by shallow platforms (Katsikatsos 1992). The early shallow character, of the Ionian basin, during the pre-rift period, is reflected on its older rocks, which include the Permian-Triassic evaporites and dolomites and the neritic Pantokrator limestones of Upper Triassic age,, extending mainly to the west part of the study area. During the Lower Jurassic - Upper Jurassic rift period, the Lower siliceous shales with Posidonomya, the red-blue limestones with ammonites (Ammonitico Rosso), the filamentous limestones and the Upper siliceous shales with Posidonomya were deposited (Renz, 1955). The syn-rift formations are overlain by the Upper Jurassic - Lower Cretaceous pelagic Vigla Limestone Formation (Aubouin, 1959; Karakitsios and Koletti, 1992; Karakitsios et al., 2004). The Gavrovo-Tripolitza 
Zone includes shallow platform carbonate rocks of Cretaceous-Eocene age, which are covered by vast quantities of detrital sediments (De Wever, 1975; Fleury, 1980). The sedimentary rocks of the Pindos Zone (Fig. 1) originate from an elongate remnant ocean basin that formed during mid-Triassic, consisting typically of deep-water carbonate, siliciclastic and siliceous rocks, ranging in age from Late Triassic to Eocene, covered by thick detrital, late Paleocene to Oligocene flysch sediments (Fleury, 1980; Robertson et al., 1991; Robertson, 1994; Degnan and Robertson, 1998; Degnan and Robertson, 2006).

The lower stratigraphic unit in the Pindos Zone is the Priolithos formation of Kar- nian age comprising medium-grained sandstone with mudstone intercalations (Fig. 2). Overlying to the Priolithos formation is the Drimos formation composed of turbiditic and hemipelagic limestone. The Lestenna formation overlies the Drimos formation comprising, from bottom to top, the Kastelli mudstone member, mainly composed of multicolored mudstone, the Aroania member, consisting of Jurassic radiolarites and the first flysch, which includes pelites, limestone and sandstone, red mudstone. Subsequently, Lower Cretaceous to Maastrictian, redeposited limestone and pelagic limestone were formed. The Kataraktis Passage member overlies this formation, comprising the transition from car-

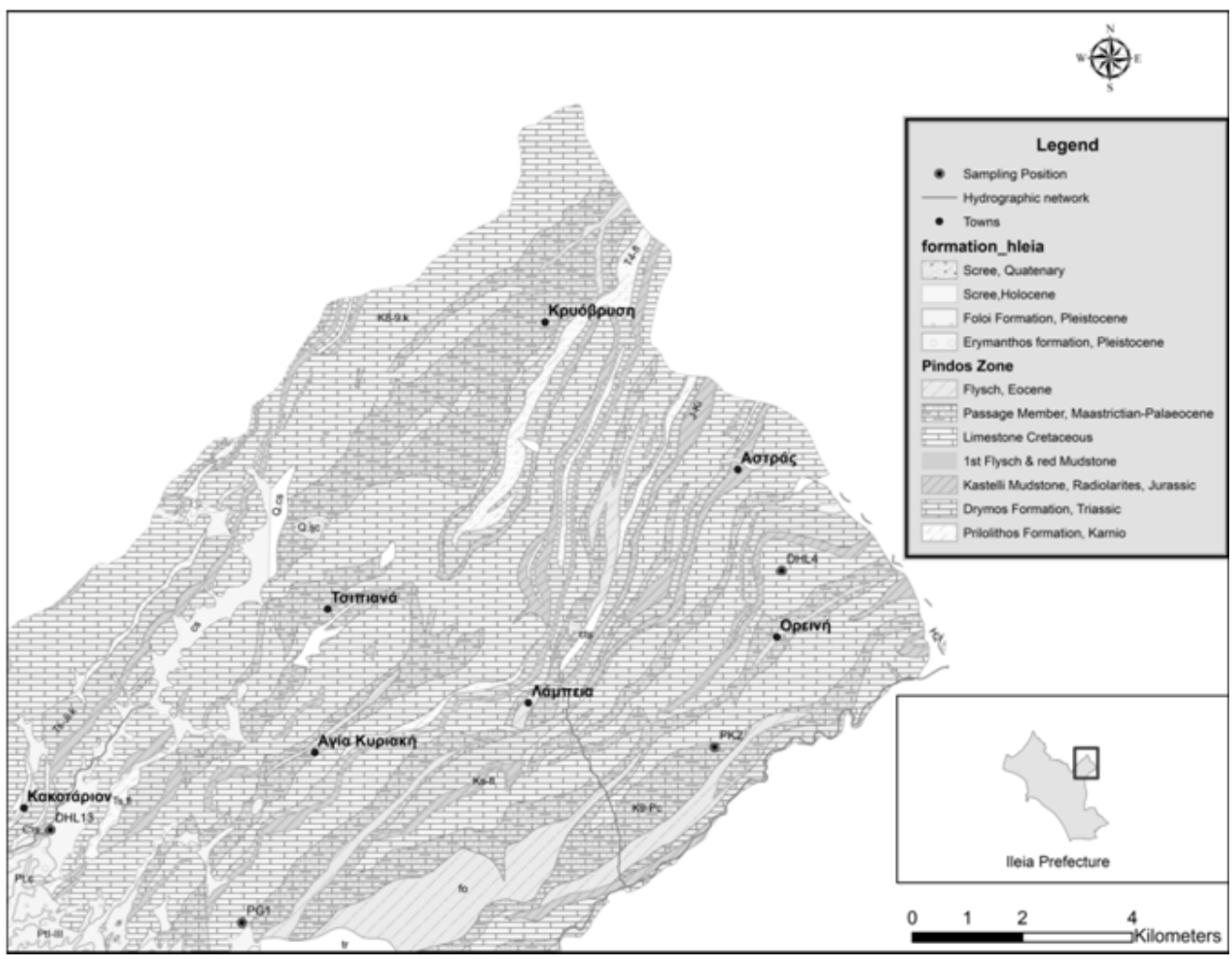

Fig. 1. Geological map of eastern lleia Prefecture.

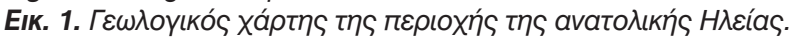


bonate to detrital sedimentation. It includes pure limestone deposition at its base with increasing clastic input towards the top. Finally, the late Palaeocene-early Eocene Pindos flysch lies at the top of the pile, likely extending also to Mid-Eocene age in the SE Peloponnesus (Piper, 2006). The investigated Cretaceous carbonate rocks record a transitional time period between major orogenic cycles in the Hellenides (Kaf-

Flysch

Kataraktis Passage Member

Limestone

First Flysch \& Red Mudstone

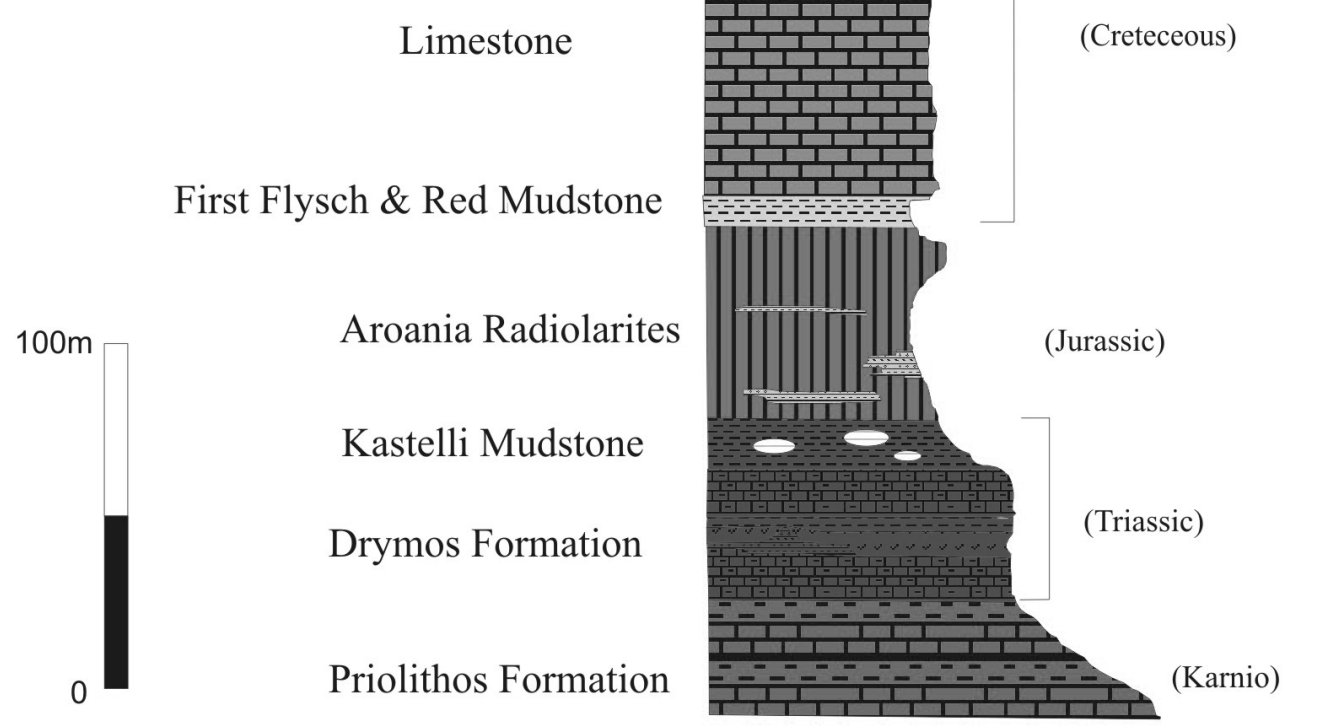

ousia et al., 2010). These cycles culminated in the latest Jurassic - Early Cretaceous (Eohellenic phase) and the latest Cretaceous to Tertiary (Mesohellenic and Neohellenic phases) and led to the westerly directed progressive suturing of the Hellenides (Neumann and Zacher, 2004).

\section{Analytical methods}

Determination of physical properties of

Fig. 2. Simplified stratigraphic section of the Pindos zone at lleia Prefecture.

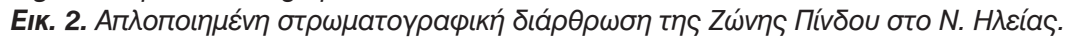


the limestones was conducted in the Research Laboratory of Minerals and Rocks, Department of Geology, University of Patras. The insoluble residue was determined after digestion in 25 vol.\% acetic acid (Hirst and NicholIs, 1958). The mineralogical composition of the insoluble residue was determined by X-Ray Diffraction (XRD), using a Bruker D8 Advance diffractometer equipped with a LynxEye ${ }^{\circledR}$ detector, at a $3-7002 \theta$ range with, a scanning step of $0.015^{\circ}$ and 0.2 seconds time per step. The diffractograms were evaluated using the EVA v.12 software. The clay mineralogy was determined from three XRD patterns in oriented samples (after air-drying at $250 \mathrm{C}$, with ethylene glycol treatment, and after heating at $4900 \mathrm{C}$ for 2 hours). The organic carbon content was determined with titration according to Walkley and Black (1934) A Hunter color measuring system (Hunter Color Diff. Meter, Miniscan XE plus, Hunter Associates Laboratory Inc., Reston, VA) was used to measure the color. Individual corms were cut transversely and each sample was measured thrice for color values. The information given by $L^{*}, a^{*}$, and $b^{*}$ is generally expressed as the total color, with $L^{*}$ representing the brightness or dullness, $a^{*}$ for redness to greenness, and $b$ * for yellowness to blueness. The colour properties of the carbonate powder were measured according to the CIELAB system using a Diffusion Systems. The source UV content is nominal match to D65 with port diameters $45 / 0$. The physical properties investigated included moisture content (ASTM D2216), water absorption (ASTM C97-47), bulk specific gravity (AASHTO TIOO-T85) and apparent specific gravity (AASHTO T147). Three tests were performed for each property and the mean values were recorded. Porosity values $(\mathrm{n} \%)$ were calculated on rock powders using a pycnometer, according to the ISRM (1981) specification. The total volume of pores is calculated as the difference between the volume of the specimen and that of the powdered particles. Whole rock chemical analyses were performed at Activation Laboratories LTD, Ancaster, Ontario, by fusion ICP-OES for major elements and combined ICPMS and INAA for trace elements. Detection limit for major elements is $0.01 \%$, except for $\mathrm{TiO} 2$ which is $0.005 \%$. Replicate analyses suggest precision better than $5 \%$ for major elements and most trace elements. The determination of $\mathrm{CO}_{2}$ was carried out by coulometry.

\section{Results \\ Petrography}

Thirty five samples were collected from the Cretaceous limestones and petrographically examined, representing the whole stratigraphic sequence and geographic distribution. The investigated samples were classified after the classification schemes of Dunham (1962) and Folk (1959, 1962). The observed lithotypes include medium-sorted rudstones or oointrabiomicrosparite, which are clast-supported monomict rocks but matrix supported fabric are also detected. Clasts are sub-rounded, mostly composed of micrite and dark oolites (Fig. 3a). Other clasts include reworked limestone containing benthic foraminifera (texturlaria, miliolidae) (Fig. 3b). These samples occur at the slope of the pelagic formations attached to the GavrovoTripolitza Zone. Coarse crystalline, subhedral dolostones contain rhombohedral dolomite grains (Fig. 3c), which frequently display cloudy cores and clear rims (a common feature in replacement dolomite) that have completely obliterated primary fabric and micritic matrix. 
These samples are classified as crystalline dolomitic limestones according to Dunham (1962) and as dolocalcitic sparstones according to Wright (1992). Primary and secondary types of porosity were also observed and classified according to the Choquette and Pray (1970) scheme (Fig. 3d). Mudstones or dismicrites contain micritic calcite while mudstones with bioclasts or-fossiliferous micrites contain micritic calcite with bioclasts mainly foraminifera (Figs 4a, b). Wackestones or mudstones with bioclasts are composed predominately of
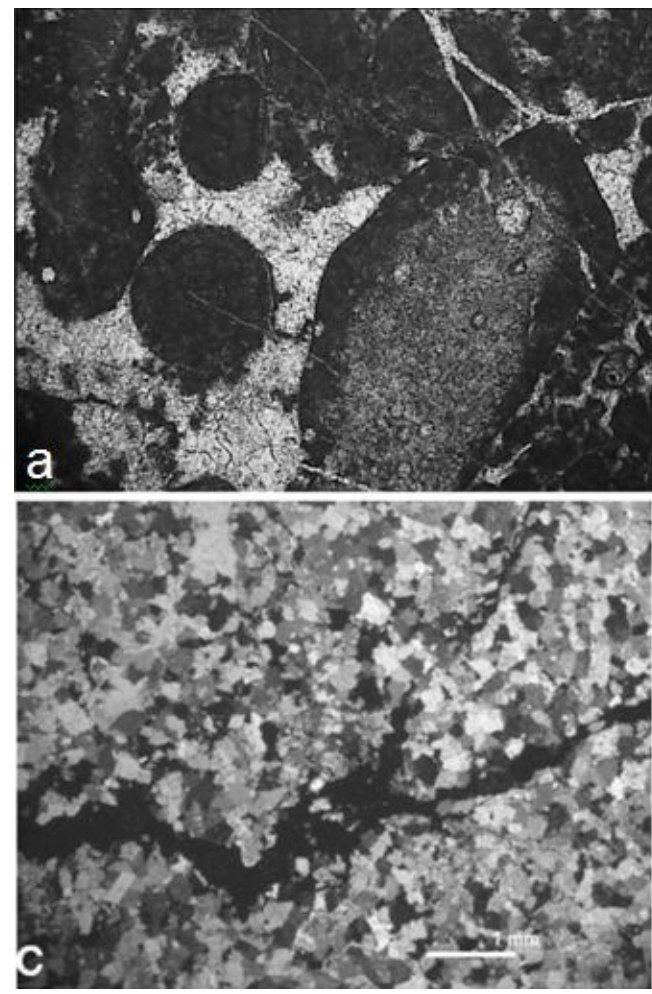

micrite matrix that supports sparse bioclast. Radiolarian fauna (Fig. 4d), typically found in Early and mid-Cretaceous, in these wackestones show poor to medium preservation due to reworking and corrosion (Neumann and Zacher 2004). The presence of stylolites is associated with uplift and load release, which commonly leads to separation of the rock fabric along weak surfaces (Figs 3c, 4a, 4c). Sometimes clay rich stylolites (Fig. $4 \mathrm{~b}, 4 \mathrm{c})$ generate elongated and often unconnected secondary porosity zones (Scholle and Ulmer-Scholle, 2003.
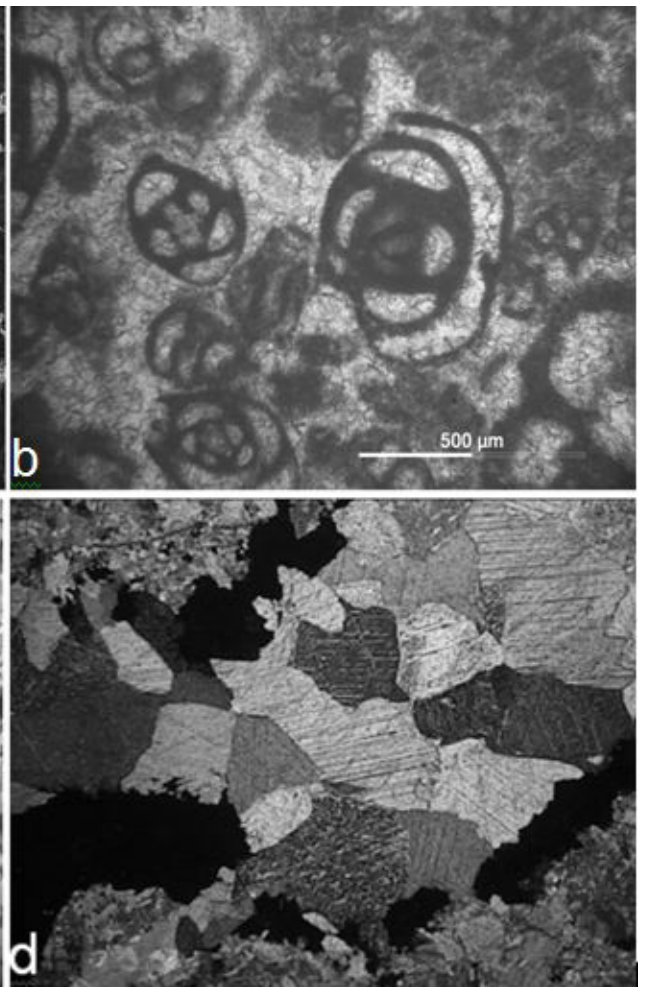

Fig. 3. Photomicrographs of the studied limestones: (a) Intraclast with oolite in a rudstone (sample DHL 13, plane polarized light); (b) Abundant foraminifera cemented with fine-crystalline calcite (rudstone sample DHL 13, plane polarized light); (c) Coarse crystalline, rombohedral dolomite in crystalline dolomitic limestone (sample DHL 12B, crossed polarized light); (d) Channel porosity within crystalline calcite (sample DHL 12B, crossed polarized light).

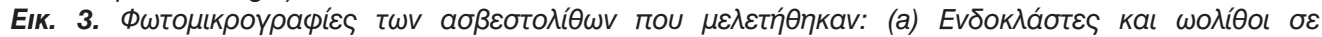

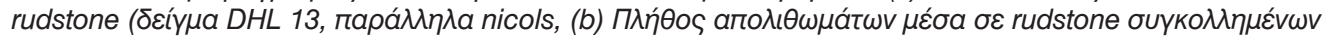

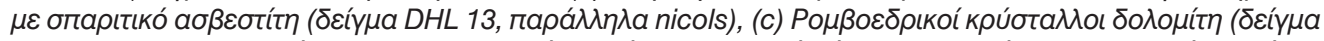

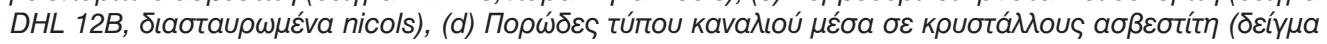

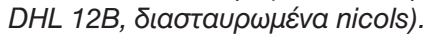



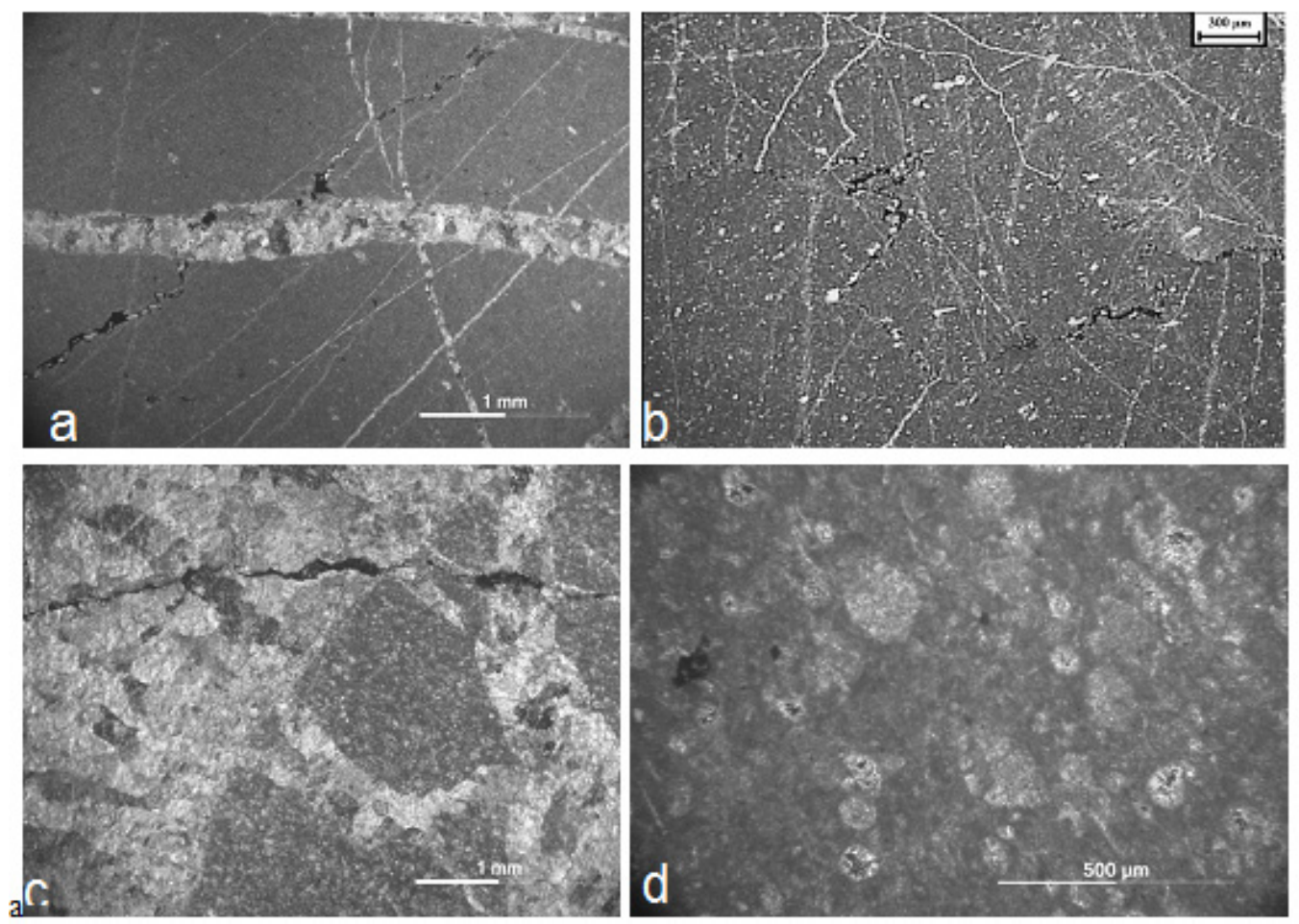

Fig. 4. (a) Dismicrite with veins and stylolite filled with calcite (sample $D H L 4 B$, crossed polarized light); (b) fossiliferous micrite with stylolite filled with clay minerals (sample DHL 23B, crossed polarized light); (c) calcite vein and stylolite in a wackestone (sample PF1B, crossed polarized light); (d) radiolarian bioclasts in a wackestone (sample DHL 19, crossed polarized light).

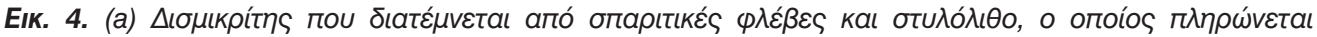

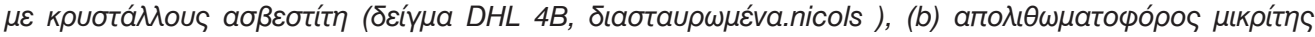

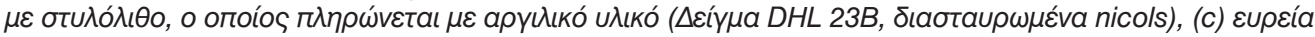

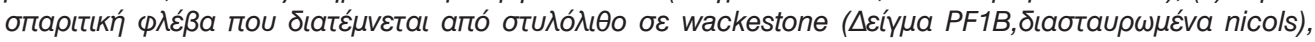

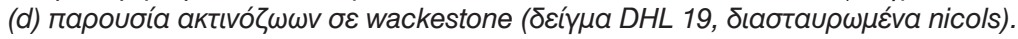

\section{X-Ray Diffraction}

X-Ray diffraction patterns of random powder mounts revealed the presence of calcite in all samples except for dolomitic limestones where dolomite is also present. The insoluble residue is dominated by smectite, chlorite, illite and vermiculite. In some samples traces of mixed-layer illite-chlorite were also present. The presence of smectite was detected by a diffraction maximum at $15 \AA$ in the air dried sample, which is shifted at $16.9 \AA$ after treatment with ethylene glycol and at $10 \AA$ after heating at 4900 . II- lite is identified by the reflections at $10 \AA$, $5 \AA$ and $3.3 \AA$, which remain unaffected after ethylene glycol treatment and heating (Moore and Reynolds, 1989). Chlorite was identified by the reflections at $14.2 \AA, 7.1 \AA, 4.77 \AA$ and $3.55 \AA$ and vermiculite by the peak at $14.5 \AA$, which remains unaffected after ethylene glycol treatment. The mixed layer illite-chlorite was identified by the diffraction maximum at $12 \AA$ and at about 7 to $7.98 \AA$, which was not affected by ethylene glycol treatment (Thorez, 1976, Reynolds, 1980, Ruiz-Cruz, 2001). 


\section{Physical properties}

Knowledge of the physicochemical properties of carbonate rocks is essential in order to determine their quality. Physical properties were determined in ten representative samples and the results are given in Table 1.

Moisture content of the studied limestone ranges between $0.07-0.42 \%$ whereas their water absorption (Wa) values range between $0.07-2.67 \%$ (Tab. 1). Total porosity (nt) is an important factor in rock strength, since a small change in pore volume can produce an appreciable mechanical effect (ISRM, 1981). The nt values obtained for the limestones range between 0.37 - $0.85 \%$. Total Organic Carbon (TOC) ranges between $0.09-0.29 \%$ and insolu- ble residue range between 1.08-5.69\%. Rudstone and grainstone have the lowest content in TOC and insoluble residue. The positive values of colour parameter $b^{*}$ (yellowness) in the packstones, which have low TOC contents and insoluble residue, show that these samples are in the range of light yellow colour (Tab. 1). Mudstone and wackestone have higher parameter $b^{*}$ values than other lithotypes. With increasing total organic carbon and insoluble residue redness-greeness and yellowness of the samples increase. The TOC and insoluble residue are inversely correlated to the colour index $L$ with the following empirical equations: TOC $=-0,0142$ $L+1.421$ and $I R=-0.2691 L+27.266$ (Fig. 5).

\begin{tabular}{|c|c|c|c|c|c|c|c|c|c|c|}
\hline Sample & DHL 4B & DHL 128 & DHL 13 & DHL 19 & DHL 20B & $\mathrm{OHL} 21$ & $\mathrm{DHL}$ 23B & G1B & PF1B & PK2A \\
\hline Dunham(1962) & mudstone & $\begin{array}{c}\text { Crystalline dolomitic } \\
\text { limestone }\end{array}$ & Rudstone & $\begin{array}{c}\text { wackestone with } \\
\text { radiolarian }\end{array}$ & mudsotne & packstone & $\begin{array}{l}\text { mudstone with } \\
\text { bioclast }\end{array}$ & grainstone & wackestone & packstone \\
\hline moisure content $(56), n=3$ & 0.10 & 0.14 & 0.08 & 0.42 & 0.14 & 0.31 & 0.53 & 0.07 & 0.40 & 0.13 \\
\hline water absorption $(55), n=3$ & 0.45 & 2.67 & 0.09 & 0.83 & 0.32 & 0.80 & 1.57 & 1.32 & 0.07 & 0.05 \\
\hline void ratio & 1.51 & 2.55 & 1.34 & 0.58 & 1.35 & 7.53 & 2.05 & 5.75 & 3.53 & 3.43 \\
\hline ap.spec.grav $(g r / \mathrm{cm} 3), n=3$ & 2.69 & 2.62 & 2.69 & 2.62 & 2.64 & 264 & 2.64 & 2.61 & 2.65 & 2.65 \\
\hline $\begin{array}{l}\text { bulk spec.gravity } \\
\text { (gr/cm3), } n=3\end{array}$ & 2.73 & 2.69 & 2.72 & 2.64 & 2.68 & 284 & 2.69 & 2.76 & 2.74 & 2.74 \\
\hline total porosity [\$S & 0.60 & 0.72 & 0.57 & 0.37 & 0.58 & 0.88 & 0.67 & 0.85 & 0.78 & 0.77 \\
\hline 1 & 93.03 & 95.12 & 93.72 & 83.08 & 78.97 & 84.20 & 89.46 & 93.97 & 90.25 & 90.79 \\
\hline 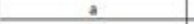 & 0.42 & 0.19 & 0.37 & -0.50 & 7.81 & 207 & 0.35 & 0.43 & 0.73 & 0.84 \\
\hline b & 4.08 & 2.80 & 3.16 & 2.65 & 11.32 & 5.03 & 5.69 & 4,31 & 705 & 4.49 \\
\hline wo & 62.39 & 76.03 & 20.40 & 21.03 & 11.65 & 41.21 & 48.07 & 66.47 & 43.59 & 56.98 \\
\hline insol. Residue (\%) & 2.94 & 1.08 & 1.23 & 5.40 & 5.69 & 3.26 & 5.43 & 1.25 & 3.49 & 2.69 \\
\hline $\operatorname{Toc}(5), n=3$ & 0.09 & 0.03 & 0.10 & 0.26 & 0.29 & 0.24 & 0.15 & 0.14 & 0.14 & 0.14 \\
\hline $\mathrm{CaO}(\mathrm{S})$ & 54.71 & 49.93 & 55.03 & 48.84 & 48.64 & 53.73 & $\$ 1.48$ & 55.37 & 52.16 & 55.67 \\
\hline
\end{tabular}

Tab. 1. Mean values of physical properties of the investigated carbonate samples from the lleia Prefecture.

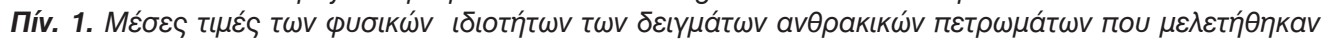

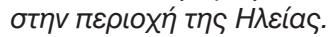
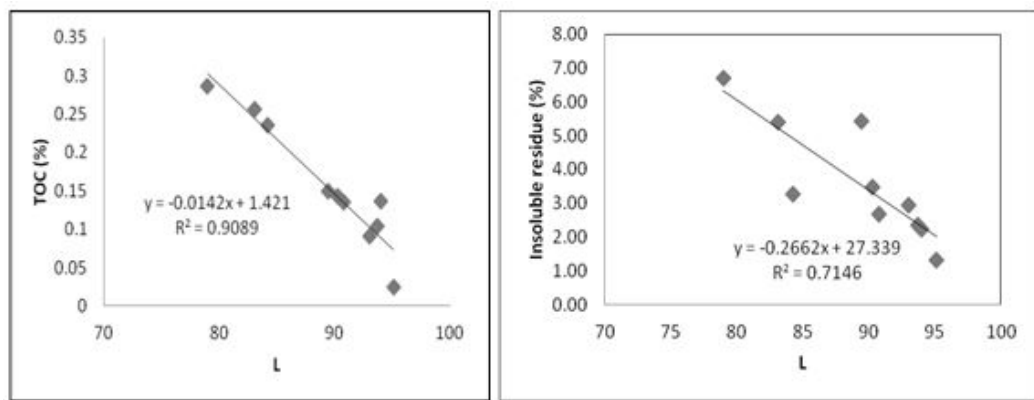

Fig. 5. Correlation diagrams of the total organic carbon and insoluble residue with the colour $L^{*}$ parameter.

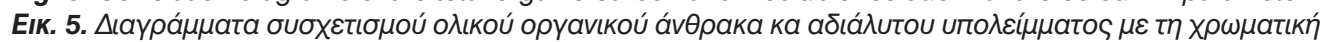

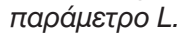


Water absorption shows well defined inverse correlation with the $\mathrm{CaO}$ content, except for the mudstone samples (Fig. $6 a)$. Moisture content is positively correlated with insoluble residue, suggesting that clay minerals are the prevalent water adsorbents (Fig. 6b). However, in samples containing abundant quartz in the insoluble residue (DHL 19, DHL 20B) the relationship is not well determined. They are related each other with the empirical equations: $\mathrm{Wa}=-0.4371 \mathrm{CaO}+$ 1.421 and $I R=8.6576$ m.c +0.8631

\section{Geochemistry}

Whole-rock geochemical analyses from representative carbonate rocks are listed in Tab. 2. The analyzed limestone samples have $\mathrm{CaO}$ content between
48.64 and 55.67 wt.\% with minor to moderate $\mathrm{SiO}_{2}$ and $\mathrm{Al}_{2} \mathrm{O}_{3}$ abundances (Fig. 7). According to the chemical classification based on $\mathrm{CaCO}_{3}$ content (Oates 1998), grainstone and rudstone are characterized as ultra-high pure calcium limestones $\left(\mathrm{CaCO}_{3}>98.5 \%\right)$, except for the crystalline dolomitic limestone, which due to the presence of $\mathrm{MgO}$ shows much lower $\mathrm{CaCO}_{3}$ contents. Packstones are characterized as calcium limestones of high purity $\left(\mathrm{CaCO}_{3}=\right.$ 97-98.5\%) and median purity limestones $\left(\mathrm{CaCO}_{3}=93.5-97.0 \%\right)$. Mudstones and wackestones are characterized as low calcium limestones $\left(\mathrm{CaCO}_{3}=85.0\right.$ 93.5\%) except for DHL 4B which is classified as highly pure limestone.
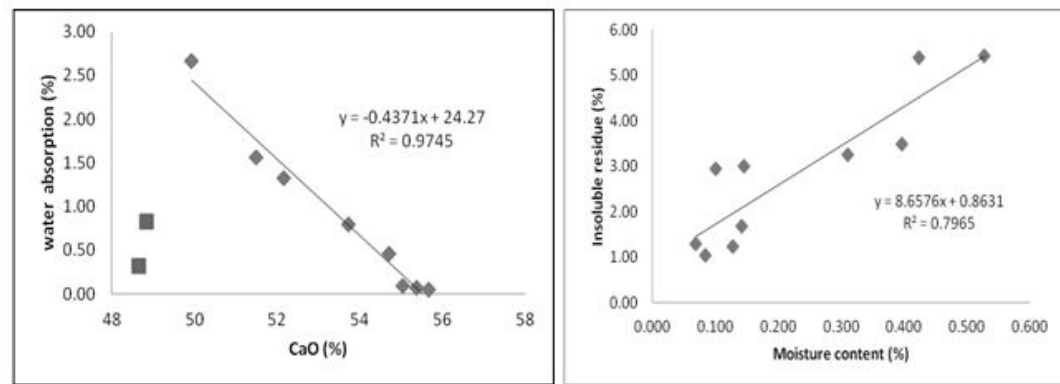

Fig. 6. Plot of water absorption vs. CaO content and moisture content vs. insoluble residue for the Cretaceous carbonate samples from lleia Prefecture.

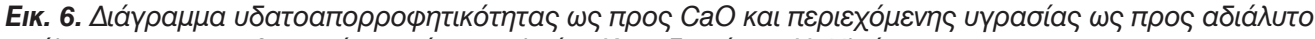

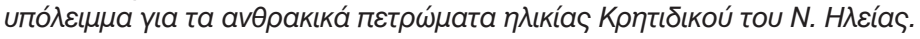

\begin{tabular}{lrrrrrrrrrr}
\multicolumn{10}{l}{ Majior elements (wt.\%) } \\
\hline & DHL 4B & DHL 12B & DHL 13 & DHL 19 & DHL 20B & DHL 21 & DHL 23B & PF1 B & G1 B & PK2 A \\
\hline $\mathrm{SiO}_{2}$ & 1.86 & 1.63 & 0.64 & 10.32 & 11.15 & 2.40 & 5.70 & 4.72 & 0.34 & 0.92 \\
$\mathrm{Al}_{2} \mathrm{O}_{3}$ & 0.35 & 0.35 & 0.11 & 0.72 & 1.00 & 0.28 & 1.09 & 0.72 & 0.08 & 0.18 \\
$\mathrm{Fe}_{2} \mathrm{O}_{3}{ }^{\circ}$ & 0.26 & 0.14 & 0.13 & 0.44 & 0.43 & 0.33 & 0.51 & 1.34 & 0.11 & 0.15 \\
$\mathrm{MnO}$ & 0.06 & 0.02 & 0.04 & 0.13 & 0.11 & 0.04 & 0.06 & 0.09 & 0.03 & 0.04 \\
$\mathrm{MgO}$ & 0.34 & 3.84 & 0.36 & 0.54 & 0.52 & 0.34 & 0.48 & 0.34 & 0.31 & 0.31 \\
$\mathrm{CaO}_{2}$ & 54.71 & 49.93 & 55.03 & 48.84 & 48.64 & 53.73 & 51.48 & 52.16 & 55.37 & 55.67 \\
$\mathrm{Na}_{3} \mathrm{O}$ & 0.05 & 0.04 & 0.06 & 0.03 & 0.07 & 0.02 & 0.05 & 0.02 & 0.03 & 0.03 \\
$\mathrm{~K}_{2} \mathrm{O}$ & 0.07 & 0.07 & - & 0.15 & 0.18 & 0.06 & 0.18 & 0.12 & 0.04 & 0.06 \\
$\mathrm{TiO}_{2}$ & - & - & - & 0.025 & 0.021 & - & 0.039 & 0.022 & - & - \\
$\mathrm{P}_{2} \mathrm{O}_{3}$ & 0.03 & 0.03 & 0.02 & 0.01 & 0.04 & 0.02 & 0.03 & 0.02 & 0.01 & 0.02 \\
$\mathrm{LOI}$ & 42.70 & 43.27 & 43.43 & 39.00 & 38.36 & 42.56 & 40.64 & 41.37 & 43.51 & 43.14 \\
$\mathrm{Total}^{2}$ & 100.40 & 99.34 & 99.81 & 100.20 & 100.50 & 99.78 & 100.30 & 100.90 & 99.83 & 100.5 \\
$\mathrm{CaCO}_{3}$ & 97.02 & 93.82 & 98.65 & 87.66 & 86.57 & 96.50 & 91.84 & 92.70 & 99.05 & 98.32 \\
\hline
\end{tabular}




\begin{tabular}{|c|c|c|c|c|c|c|c|c|c|c|}
\hline \multicolumn{11}{|c|}{ Trace elements (ppm) } \\
\hline $\mathrm{Ba}$ & 45 & 12 & 5 & 78 & 27 & 7 & 25 & 16 & 6 & 6 \\
\hline $\mathrm{CQ}$ & 5 & 4 & 6 & 5 & 9 & 3 & 4 & 3 & 4 & 4 \\
\hline $\mathrm{Cr}$ & 3 & 4 & 5 & 27 & 8 & 3 & 13 & 9 & 2 & 3 \\
\hline $\mathrm{Cy}$ & 8 & 3 & 4 & 4 & 55 & 3 & 11 & 8 & 5 & 4 \\
\hline $\mathrm{Ni}$ & 5 & 2 & 2 & 5 & 30 & 4 & 19 & 9 & 3 & 3 \\
\hline $\mathrm{S}(\%)$ & 0.011 & 0.005 & 0.014 & 0.008 & 0.017 & 0.009 & 0.009 & 0.008 & 0.01 & 0.009 \\
\hline $\mathrm{S} \&$ & 0.7 & 1.3 & 0.3 & 1.4 & 1.6 & 0.5 & 1.5 & 1 & 0.2 & 0.4 \\
\hline St & 660 & 74 & 343 & 431 & 590 & 628 & 811 & 945 & 392 & 671 \\
\hline $\mathrm{Y}$ & 5 & 61 & 5 & 15 & 14 & 3 & 5 & 5 & 2 & 2 \\
\hline $\mathrm{Zn}$ & 5 & 7 & 4 & 9 & 16 & 5 & 13 & 7 & 3 & 4 \\
\hline $\mathrm{Ztr}$ & 3 & 360 & 30 & 9 & 10 & 4 & 19 & 9 & 3 & 15 \\
\hline
\end{tabular}

Tab. 2. Whole-rock geochemical analyses of representative samples of Cretaceous limestones from Ileia Perfecture (-): below detection limit).

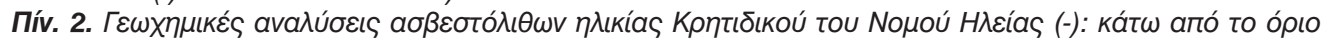

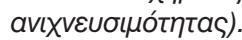

The total amount of impurities (sum of all oxides excluding $\mathrm{CaO}$ and $\mathrm{CO}_{2}$ ) for grainstone and rudstones ranges between 0.01 and 3.34 wt. \%. The $\mathrm{SiO}_{2}$ content is $0.34-1.65 \%$ and the $\mathrm{Al}_{2} \mathrm{O}_{3}$ content ranges between 0.08 and $0.35 \%$. The $\mathrm{SiO}_{2}$ content is higher in the packstones than in the grainstones. Mudstones and wackestones show the highest amount of $\mathrm{SiO}_{2}$ and $\mathrm{Al}_{2} \mathrm{O}_{3}$. High $\mathrm{SiO}_{2}$ and $\mathrm{Al}_{2} \mathrm{O}_{3}$ contents are related with the presence of quartz and clay minerals in the insoluble residue in these samples. All samples are poor in $\mathrm{MgO}(<1 \%)$, except for the dolomtitic limestone with $\mathrm{MgO}$ content of 3.84 wt.\%, due to the presence of dolomite. The mudstones have higher amounts of $\mathrm{Fe}_{2} \mathrm{O}_{3}$ than the rest samples. The concentrations of $\mathrm{MnO}, \mathrm{Na}_{2} \mathrm{O}$, are very low in all the analyzed samples. The low concentration of phosphorus reflects the absence of apatite in the samples, a mineral that is easily altered during diagenesis (Parekh et al., 1977; Cullers, 2002). Sr was detected in all samples, however the amount of $\mathrm{Sr}$ in the dolomitic limestone (DHL 12B) is lower than the rest samples. $\mathrm{Sr}$ is easily mobilized during weathering, especially in oxidizing, acid environments, thus it is incorporated in clay minerals.
Sr plays an important role to the cycling (Zhao et al., 2009, Kabata-Pendias 2011). The mudstone samples display high $\mathrm{Ba}$ contents. The enrichment of $\mathrm{Ba}$ in limestones indicates high productivity in the upper part of the sea column similar to the high concentrations of barite reported at the bottom of the Mediterranean (Passier et al.,1999; Tenger et al., 2005). Ba is also strongly adsorbed by clay minerals and it commonly substitutes for $\mathrm{K}$ in feldspars (Kabata-Pendias, 2011). Sample DHL 20B demonstrates the highest $\mathrm{Cu}$ values compared to the remaining samples.

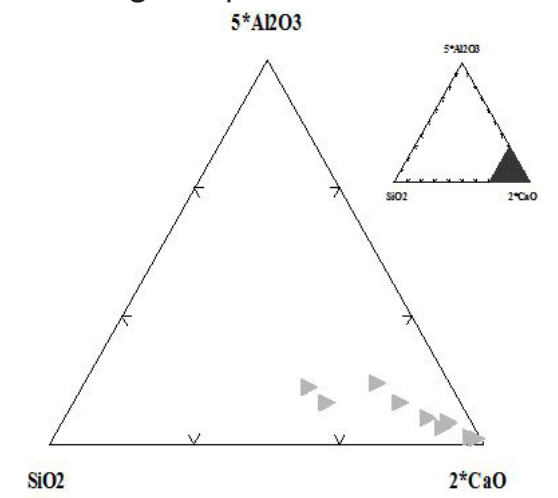

Fig. 7. Plot of the analysed samples on the $\mathrm{Al}_{2} \mathrm{O}_{3}$ $\mathrm{SiO}_{2}-\mathrm{CaO}$ diagram for sedimentary rocks.

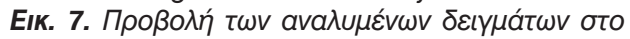

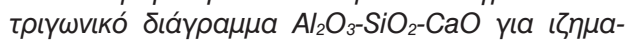

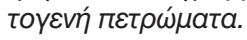




\section{Discussion-Conclusions}

The Cretaceous succession of the Olonos -Pindos Zone has recorded the sedimentary history of a complex marginal basin aligned to the north eastern Apulian passive margin, in which tectonism, sediment supply and palaeoceanographic effects have influenced the slope and basin plain sedimentation. The autochthonous rocks compose pelagic limestone while the allochthonous ones comprise thin intercalation siliceous, pelitic and organic rich facies of Early and Mid Cretaceous age (Neumann and Zacher, 2004). The carbonate samples include a variety of lithotypes such as mudstones, wackestones, packstones, grainstone and rudstones. In thin sections veinlets of calcite are observed and stylolites are often associated with insoluble material (mainly clay minerals) accumulated as a result of pressure-induced dissolution.

Physical properties of the studied samples were determined on both the wholerock and powdered material. There is an excellent negative relationship between water absorption and $\mathrm{CaO}$ content, except for the mudstones, which are rich in $\mathrm{SiO}_{2}$ indicating that impurities play a significant role in the absorption of water. Furthermore, moisture content is positively correlated with insoluble residue probably due to the presence of absorbent clay minerals. The colour index is negatively correlated with the insoluble residue and TOC, suggesting that they both have a negative affection on the aesthetic appearance of limestones. Impurities in carbonate rocks may show variable compositions and amounts and may affect their properties. A considerable amount of some impurities may be tolerated in carbonate rocks for some uses, if they are finely disseminated throughout the rocks. On the other hand, if the impurities are concentrated in distinct laminae, they may form planes of weakness that seriously affect the performance of the rocks (Boynton, 1980; Harben, 1992; Carr et al., 1994; Oates, 1998; Christidis et al., 2004).

Generally, high contents of magnesium carbonate are undesirable in cement industries. The level of $\mathrm{MgO}$ in the clinker should not exceed $5 \%$ and indeed, many cement producers favour an upper limit of $3 \%$, so dolomitic and magnesian limestones are unsuitable for cement production. The $\mathrm{CaCO}_{3}$ content in all analyzed samples lies above $87 \%$ (Tab. 2, Fig. 8a) and the samples have low MgO contents, thus comprising suitable materials for cement production, except the dolomite horizons occurring in the Cretaceous carbonate rocks (Fig. 8b). According to Rigas et al. (1990) pure limestones have insoluble residues less than $0.03 \%$, while impure limestones show insoluble residues higher than $5.5 \%$. The Cretaceous limestone from lleia show a broad range of insoluble residues (Fig. $8 c)$ and they are characterized as pure, medium pure (with insoluble residue between 0.03 and $5.50 \%$ ) and impure.

The $\mathrm{CaCO}_{3}$ content in the lleia Cretaceous carbonates exceeds the limit of $65 \%$ for suitability in cement production. However, the Mg abundance, the insoluble residue, the total organic carbon and the colour index suggest that only grainstones (G1B) and rudstone (DHL 13) are suitable for cement production (Fig. 8). All the studied limestones are suitable as $\mathrm{pH}$ regulators in acid soils, as well as additives of fertilizers because the $\mathrm{CaCO}_{3}$ content exceeds $60 \%$ and the $\mathrm{MgO}$ content is below 5\% (Fig. 8). The grainstones $(\mathrm{G} 1 \mathrm{~B})$, rudstones (DHL 13) and packstones (DHL 21, PK2A) are suitable for desulphurization of exhaust gases because the $\mathrm{CaCO}_{3}$ content ex- 
ceeds $95 \%$, and very low $\mathrm{Al}_{2} \mathrm{O}_{3}(<1 \%)$, $\mathrm{SiO}_{2}$ and $\mathrm{MgO}$ contents $(<2 \%$; Figs 8 and 9).

.From this study, it appears that petrographic investigation coupled by miner- alogical and geochemical analysis are useful in assessing the quality of limestones, despite the fact that several physical properties cannot be directly evaluated.
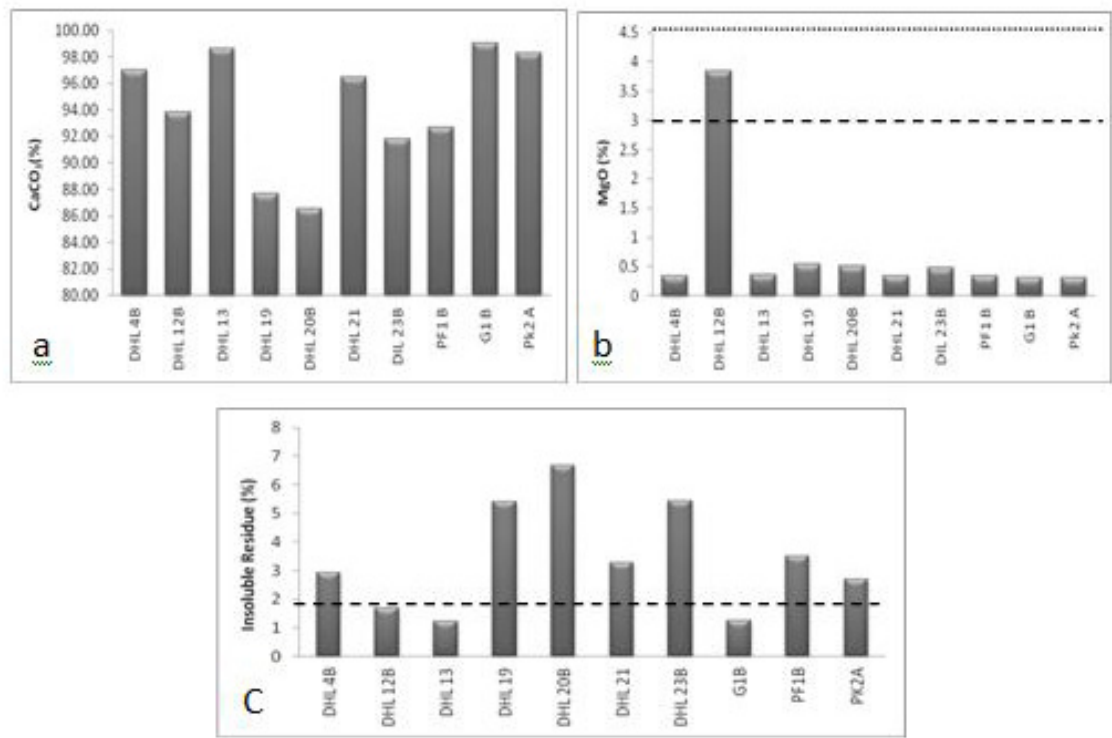

Fig. 8. Variation of $\mathrm{CaCO}_{3}$ content (a), $\mathrm{MgO}$ (b) and insoluble residue (c) of the analyzed Cretaceous limestone samples. Dashed lines indicate the suitability limits for use of carbonate rocks in cement industry. Dotted lines indicate the suitability limits for use of carbonate rocks as fertilizers (Boynton, 1980; Harben, 1992; Oates , 1998).

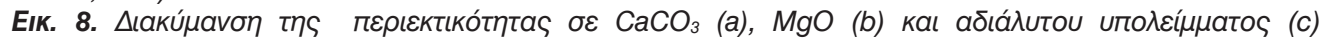

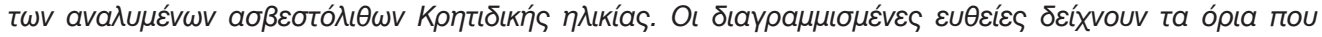

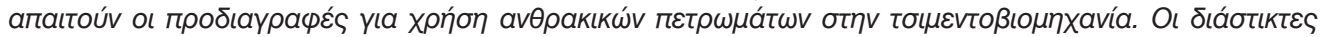

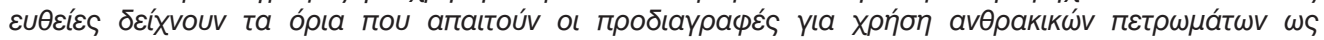
$\varepsilon \delta a \varphi \circ \beta \varepsilon \lambda \tau \iota \omega \tau \iota k \omega ́ v$ (Boynton, 1980; Harben, 1992; Oates ,1998).

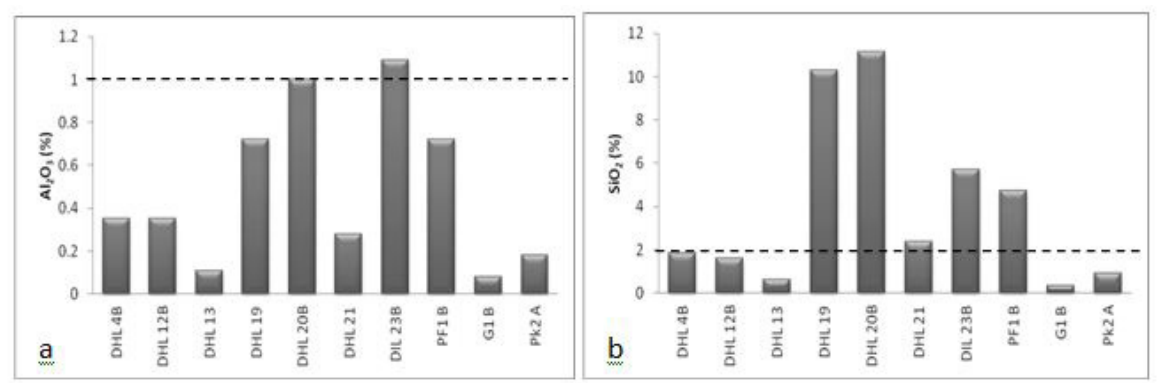

Fig. 9. Variation of $\mathrm{Al}_{2} \mathrm{O}_{3}$ (a) and $\mathrm{SiO}_{2}$ (b) contents of the analyzed Cretaceous limestone samples. Dashed lines indicate the suitability limits for use of carbonate rocks in desulphurization of exhaust gases (Boynton, 1980; Harben, 1992; Carr et al., 1994; Oates, 1998).

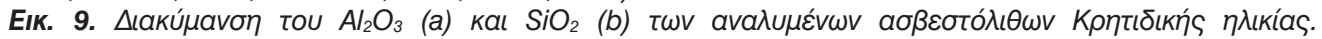

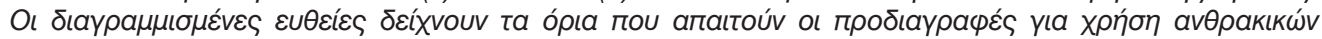

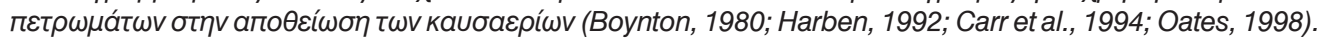




\section{Acknowledgments}

The senior author wishes to thank the Greek State Scholarship Foundation (I.K.Y.), for financial support. Professor Nikolaos Skarpelis and an anonymous reviewer are gratefully acknowledged for their substantial criticism of the manuscript.

\section{References}

Aashato T147. The Field Determination Of Density Of Soil In-Place (1954-70). Aashato T T85. Specific gravity and absorption of coarse aggregates

American Society for Testing and Materials C97-47. Standard Test methods for Laboratory determination of water absorption

American Society for Testing and Materials D2216-10. Standard Test Methods for Laboratory Determination of Water (Moisture) Content of Soil and Rock by Mass

Aubouin, J., 1959. Contribution a l'etude geoloique de la Grèce septentrional: les confins de l' Epire et de la Thessalie. Annales Géologiques des Pays Helléniques, 10, 1-483

Billmeyer, F.W., Saltzman, M., 1981. Principles of color technology, 2nd edition. Wiley Interscience, New York. Boynton, S.R., 1980. Chemistry and Technology of Limestone. 2nd edition, New York, Wiley \& Sons.

Carr, D. D., Rooney, L. F., Freas, R.C., 1994. Limestone and dolostone. In: Carr, D.D. (Ed.), Industrial minerals and rocks, 6th Edition, Society for Mining, Metallurgy and Exploration, Littleton. Colorado, pp. 605-629.

Choquette, P.W., Pray, L.C., 1970. Geological nomenclature and classification of porosity in sedimentary carbonates. American Association of Petroleum Geologists Bulletin, 54, 207-250.
Christidis, G.E., Sakellariou, N., Repouskou, E., Markopoulos, Th., 2004. Influence of organic matter and iron oxides of the color properties of a micritic limestone from Kefalonia. Kefalonia. Bulletin Geological Society of Greece. Proceedings of the 10th International Congress, Thessaloniki 2004, $72-79$

Cullers, R.L., 2002. Implications of elemental concentrations for provenance, redox conditions and metamorphic studies of shales and limestones near. Chemical Geology, 191, 305-327.

De Wever, P., 1975. Etude géologique des séries apparaissant en fenêtre sous I' alloctone pindique (série de Tripolitza et série épimetamorphique de Zarouchla). Peloponnése septentrional, Gréce. These 3eme cycle, France, Université de Lille.

Degnan, P.J., Robertson, A.H.F., 1998. Mesozoic-early Tertiary passive margin evolution of the Pindos ocean (NW Peloponnese, Greece). Sedimentary Geology, 117, 33-70

Degnan, P. J., Robertson, A.H.F., 2006. Synthesis of the tectonic-sedimentary evolution of the Mesozoic-Early Cenozoic Pindos ocean: Evidence from the NW Peloponnese, Greece. In: Robertson, A.H.F., Mountrakis, D. (Eds.). Tectonic development of the Eastern Mediterranean region. Geological Society London, Special Publications 260, 467-491.

Dunham, R. J., 1962. Classification of carbonate rocks according to their depositional texture. In: Ham, W. E. (Ed.), Classification of carbonate rocks. American Association of $\mathrm{Pe}$ troleum Geologists Memoir 1, 108121.

Fleury, J.J., 1980. Les zones de Gavrovo-Tripolitza et du Pinde-Olonos 
(Grèce Continental), et Péloponesse du Nord. Evolution d'une plate-forme et d'un bassin dans leur cadre Alpin. Societé de la Géologie de Nord, Lille Publication, 4, 1-651.

Folk, R. L., 1959. Practical petrographic classification of limestones. American Association of Petroleum Geologists Bulletin, 43, 1-38.

Folk, R. L., 1962, Spectral subdivision of limestone types. In: Ham, W. E. (Ed.), Classification of carbonate rocks. American Association of Petroleum Geologists Memoir 1, 62-84.

Harben, P.W., 1992. The industrial minerals handybook - A Guide to Markets, Specifications, and Prices. Industrial Minerals Division, Metal Bulletin PLC, United Kingdom.

Hirst, D.M., Nicholls, G.D., 1958. Techniques in sediment geochemistry-I. Separation of the detrital and non-detrital fractions of limestones. Journal of Sedimentary Petrology, 28, 461481

ISRM, 1981. In: Brown, E.T. (Ed.), ISRM Suggested Methods: Rock 654 Characterization, Testing and Monitoring. Pergamon Press, London. $211 \mathrm{pp}$

Kabata-Pendias, A., 2011. Trace elements in soils and plants, 4th edition. CRS Press, New York.

Kafousia, N., Karakitsios, V., Jenkyns, H.C., 2010. Preliminary data from the first record of the early Toarcian oceanic anoxic event in the sediments of the Pindos zone (Greece). Bulletin of the Geological Society Greece, Proceedings of the $12^{\text {th }}$ International Congress of the Geological Society of Greece, Patras 2010, 627-633.

Karakitsios, V., Kolleti, L., 1992. Critical revision of the age of the basal Vigla limestones (Ionian Zone, western Greece), based on nannoplankton and calpionellids with paleo- geographical consequences. In: Hamrsmid, B., Young, J. (Eds.), Proceedings of the Forth International Nannoplankton Association Conference, Prague 1991, Knihovnicka ZPN, 14a, 1, 165-177.

Karakitsios, V., Tsikos, H., Van Breugel, Y., Bakopoulos, I., Koletti, L., 2004. Cretaceous oceanic anoxic events in western continental Greece. Bulletin of the Geological Society of Greece, 38, 846-855.

Katsikatsos, G., 1992. Geology of Greece. Lecture notes, University of Patras

Moore, D.M., Reynolds, R.C.Jr., 1989. XRay Diffraction and the Identification and Analysis of Clay Minerals. Oxford University Press, New York.

Neumann, P., Zacher, W., 2004. The Cretaceous sedimentary history of the Pindos Basin (Greece). International Journal of Earth Sciences 93, 119-131.

Oates, J.A.H., 1998. Lime and limestone. Chemistry and technology, production and uses, Wiley-VCH Verlag.

Parekh P.P., Moler, P., Dulski, P., Basch W.M., 1977. Distribution of trace elements between carbonate and non carbonate phases of limestone. Earth and Planetary Science Letters 34, 3950.

Passier, H.F., Bosch, H., Lourens, L.J., B"ottcher, M.E., Leenders, A., Damste, J.S.S., de Lange, G.J., de Leeuw, J.W., 1999. Sulfidic Mediterranean surface waters during Pliocene sapropel formation. Nature, 397, 146149.

Piper, D.J.W., 2006. Sedimentology and tectonic setting of the Pindos Flysch of the Peloponnese, Greece, In: Robertson, A.H.F., Mountrakis, D. (Eds.), Tectonic Development of the Eastern Mediterranean Region. Geologi- 
cal Society, London, Special Publications 260, 493-505.

Renz, C., 1955. Die Vorneogene stratigraphie der Normalm sedimentaeren Formationen Griechenlands. Institute for Geology and Subsurface Reseerch, Greece $637 \mathrm{pp}$.

Reynolds, R.C., 1980. Interstratified clay minerals, In: Brindley, G.W., Brown, G. (Eds.), Crystal Structures of Clay Minerals and their X-Ray Identification. Monograph 4, Mineralogical Society London, 249-304.

Rigas, K., Soundoulounakis, N., Georgousis, G., 1990. Mineralogical chemical composition, structure and physicomechanical properties of the Greek marbles. Proceedings of the 1st Panhellenic Congress "The Hellenic Marble", Thessaloniki 2526/5/1989, Geotechnical Chamber of Greece, 179-187.

Robertson, A.H.F., 1994. Role of the tectonic facies concept in orogenic analysis and its application to Tethys in the Eastern Mediterranean region. Earth-Science Reviews, 37, 139-213.

Robertson A. H. F., Clift, P.D., Degnan, P.J., Jones, G., 1991. Palaeographic and palaeotectonic evolution of the eastern Mediterranean Neotethys. Palaeogeography, Palaeoclimatology, Palaeoecology, 87, 289-343.

Ruiz-Cruz, M.D., 2001. Mixed-layer mica-chlorite in very low-grade metaclastites from the malaguide Complex (Betic Cordilleras, Spain). Clay
Mineralogy, 36, 307-324.

Scholle, P.A., Ulmer-Scholle, Dana S., 2003. A color Guide to the Petrography of Carbonate Rocks: Grains, textures, porosity, diagenesis. AAPG Memoir No. 77, AAPG Publications , Tulsa, OK,

Tenger, K., Khoroshyy, P., Leitgeb, B., Rákhely, G., Borovok, N., Kotlyar, A., Dolgikh, DA., Zimányi, L., 2005. Complex kinetics of the electron transfer between the photoactive redox label TUPS and the heme of Cytochrome. Journal of Chemical Information and Modeling, 45, 1520-1526.

Thorez, J., 1976. Practical identification of clay minerals. A handbook for teachers and students in clay mineralogy. Dison Lelotte Belgium.

Tissot, B.P., Velte., 1984. Petroleum Formation and Occurrence. Springer Verlag, Berlin, New York.

Walkley, A., Black, I.A., 1934. An examination of the Degtjareff method for determining organic carbon in soils: Effect of variations in digestion conditions and of inorganic soil constituents. Soil Science, 63, 251-263.

Wright, V.P., 1992. A revised classification of limestone. Sedimentary Geology, 76, 177-185.

Zhao, Y.-Y., Zheng, Y.-F., Chen, F., 2009. Trace element and strontium isotope constraints on sedimentary environment of Ediacaran carbonates in southern Anhui, South China. Chemical Geology, 265, 345-362. 